\title{
BALB/C mice as a model for immunogenicity testing of food proteins on the example of egg ovalbumin
}

\author{
JUSTYNA PATRYCJA CHUDZIK-KOZŁOWSKA, DAGMARA ZŁOTKOWSKA, \\ HENRYK KOSTYRA
}

Institute of Animal Reproduction and Food Research, Polish Academy of Sciences, Olsztyn, Poland

\begin{abstract}
The aim of our study was to determine the dose and immunization scheme for commercial albumin from chicken egg white (OVA), based on immune response of mice gut mucosa. Balb/C mice were immunized orally in groups as follows: group I on day 0, 7, and $14-2 \mathrm{mg}$ of OVA, group II on day 0, 7 and 14 - $100 \mu \mathrm{g}$ of OVA, and group III on day 0, 1, 2, and $10-100 \mu \mathrm{g}$ of OVA. After 37 days mice were intraperitoneally immunized with $100 \mu \mathrm{g} O V A+C F A$. We have demonstrated that blood serum titer for specific IgG was the highest in Group I and amounted to $2^{13}$ and $2^{11}$ after 14 and 35 days, respectively. Regardless of the immunization scheme, the dose of $100 \mu \mathrm{g}$ induced lower response. All groups tested showed a slow decrease in IgG titer during four weeks of the experiment. By contrast, an intraperitoneal dose of $100 \mu \mathrm{g}$ of OVA with CFA, administered on the $37^{\text {th }}$ day of experiment, induced an increase in the end point titer (EPT) to $2^{12-13}$ in all groups studied. What is more, stimulation of specific IgAs in blood serum and fecal extracts was on a detectable level. In conclusion, the selected method of antigen delivery was able to induce dose-dependent immune response. Therefore, the presented model of orally administered antigen without adjuvant can be used in the estimation of the immunogenicity of food proteins.
\end{abstract}

Key words: mucosal immunity, GALT, OVA, JgG, IgA

(Centr Eur J Immunol 2013; 38 (4): 430-433)

\section{Introduction}

Currently, food allergies are thought to affect about $3-4 \%$ of the adult population and $6 \%$ of children and the number of food products that cause food allergies continues to grow [1]. The main reasons for this phenomenon are believed to be the development of food production technologies (the formation of 'new' allergens), the globalization of food production, and the increasingly easier access to food imports, which introduces 'new' proteins to a given geographic area, i.e. other potential allergens [2]. For these reasons, an allergy to dietary proteins is becoming a global problem. In hospitals in the U.S. and in the UK, most cases of anaphylaxis have been reported for patients with anaphylaxis caused by a single intake of a particular kind of product [3].

Food allergy is associated with the production of immunoglobulin E (IgE), and develops in two stages: after initial contact of the organism with an allergen, the production of IgE antibody is initiated, and secondary contact with the same allergen results in an allergic reaction with clinical effects [4]. The mechanism, by which food allergens sensitize, is still under investigation. However, it is assumed that the immune system of gut mucosa (GALT) is central to the induction of responses to allergens provided with food [2].

Mucosa-associated lymphoid tissue (MALT) is the largest immune organ of the human body $[1,5,6]$. The components of MALT are subdivided into the following: GALT (gut-associated lymphoid tissue) - lymphatic tissue of the mucosa and submucosa of intestines, BALT (bronchus-associated lymphoid tissue), NALT (nasal-associated lymphoid tissue), GUALT (genito-urinary-associated lymphoid tissue), S\&LGAT (salivary \& lacrimal glands-associated lymphoid tissue), and MGALT (mammary gland-associated lymphoid tissue). The function of the mucosal immune system is based on the recognition of the factors, which organism must be protected against, from those that are desirable such as the microbial flora inhabiting gut lumen [7]. Identification of the induction 
mechanisms of GALT in contact with food proteins is an important element of knowledge about food allergies occurrence or specific tolerance against them.

Gut-associated lymphoid tissue is an organized lymphoid tissue that includes nodules diffused throughout the gastrointestinal tract, aggregated lymphoid nodules, called Peyer's patches (PP), mesenteric lymph nodes (MLN) [8], as well as the mucous membrane, composed of epithelial cells and lamina propria of the gut (LP) [9]. These structures divide the GALT in an inductive part containing Peyer's patches and MLN. The Peyer's patches are responsible for antigen presentation, antigenic stimulation of the T-cells and induction of B-cells proliferation [10, 11]. A large number of IgA-producing lymphoblasts is produced in these structures. Lymphoblasts migrate with lymph to the MLN and then into the bloodstream [12, 13]. An effector part of GALT is formed by epithelial cells and LP. A special feature of this epithelium is a complete absence of polymeric immunoglobulin receptors, indicating that this tissue does not secrete IgA antibodies, which, in turn, facilitates the transfer of antigens through the mucous membrane [14]. An allergen, through the mucosa, induces a local immune response towards tolerance or allergy in these sections of the gastrointestinal tract [13].

The aim of this work was to evaluate the potential of using Balb/C mice as a model to study the influence of food proteins on the immune system response of mice gastrointestinal mucosa after low or high doses of OVA.

\section{Material and methods}

Albumin (OVA, Sigma) of egg white was used as an experimental material.

\section{Biological experiment}

The experiment was performed on mice of inbred strain Balb/C $\left(\mathrm{H}-2^{\mathrm{d}}\right)$ in the age of 6-8 weeks (Mossakows- ki Medical Research Centre, Polish Academy of Sciences, Warsaw). During the experiments mice were housed in animal facilities of the Institute of Animal Reproduction and Food Research of the Polish Academy of Sciences in Olsztyn. The culture conditions were standardized, the animals were provided constant access to food and drinking water.

Mice were divided into groups of 10 animals and were inoculated orally according to the scheme presented in Table 1 . From day 14 onwards, after immunization, blood and feces were collected from mice. Prepared serum samples and fecal extracts [15] were stored at $-20^{\circ} \mathrm{C}$ for further analysis.

The experiment was conducted in accordance with the requirements of the Local Ethics Committee, license number $81 / 2011 / \mathrm{N}$.

\section{Titer determination of specific antibodies by indirect ELISA}

Microplates (Maxisorb, Nunc) were coated with $0.4 \mathrm{mg} / \mathrm{ml}$ of OVA solution in PBS (phosphate buffered saline) (10 mM, pH 7.4) and incubated at $4^{\circ} \mathrm{C}$ for $12 \mathrm{~h}$. Then, the coating solution was removed, and unbound sites were saturated with $1 \% \mathrm{BSA}$ and incubated at $37^{\circ} \mathrm{C}$ for $1 \mathrm{~h}$. Next, plates were washed twice with PBS and twice with PBS-T (PBS with $0.05 \%$ Tween-20). This step was repeated after each incubation. Then, serial dilutions of samples were applied the microplates. Plates were incubated $12 \mathrm{~h}$ at $4^{\circ} \mathrm{C}$. The next step was the incubation of samples $\left(1.5 \mathrm{~h}\right.$ at $\left.37^{\circ} \mathrm{C}\right)$ with goat anti-mouse $\operatorname{IgG}$ or $\operatorname{IgA}$ (Sigma) conjugated to horseradish peroxidase [16]. Reaction was detected by adding a substrate for ABTS enzyme (Moss) and subsequent $1 \mathrm{~h}$ incubation at room temperature. The absorbance of samples was read at the wave length $\lambda=415$ $\mathrm{nm}$ using an automatic microplate reader (UVM JUPITER 340, Biogenet). The multiple of the last dilution for which the OD value was 0.1 higher than the negative control, was considered as the final dilution of antibodies tested (EPT).

Table 1. Schedule of oral and intraperitoneal mice immunization with ovalbumin

\begin{tabular}{|c|c|c|c|c|}
\hline Day of immunization & Group I & Group II & Group III & Control group \\
\hline 0 & $2 \mathrm{mg}$ OVA oral & $100 \mu \mathrm{g}$ OVA oral & $100 \mu \mathrm{g}$ OVA oral & $100 \mu \mathrm{l}$ PBS oral \\
\hline 1 & & & $100 \mu \mathrm{g}$ OVA oral & \\
\hline 2 & & & $100 \mu \mathrm{g}$ OVA oral & \\
\hline 7 & $2 \mathrm{mg}$ OVA oral & $100 \mu \mathrm{g}$ OVA oral & & $100 \mu \mathrm{l}$ PBS oral \\
\hline 10 & & & $100 \mu \mathrm{g}$ OVA oral & \\
\hline 14 & $2 \mathrm{mg}$ OVA oral & $100 \mu \mathrm{g}$ OVA oral & & $100 \mu \mathrm{l}$ PBS oral \\
\hline 37 & $100 \mu \mathrm{g} \mathrm{OV}$ & oneal + CFA & & $\begin{array}{c}100 \mu \mathrm{l} \text { PBS } \\
\text { intraperitoneal }\end{array}$ \\
\hline
\end{tabular}

OVA - ovalbumin, PBS - phosphate buffered saline, CFA - complete Freund's adjuvant 


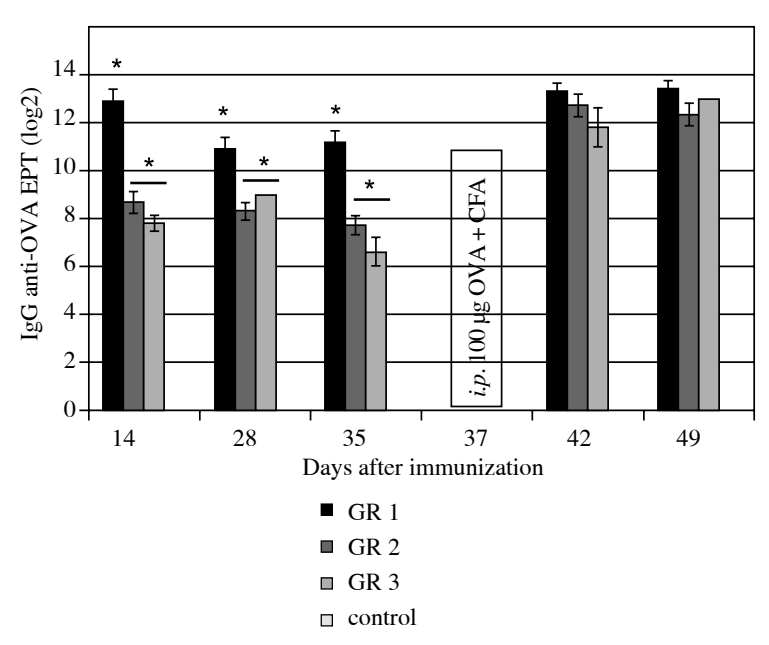

Fig. 1. The level of OVA-specific IgG serum depending on the dose of OVA. Values are expressed as means \pm SD

\section{Statistical analysis}

Results of the experiment were analyzed statistically using one-way ANOVA analysis $(p<0.05)$.

\section{Results and discussion}

The experiment compared the immune system responses of mice before and after administration of ovalbumin (OVA). The antigen was administered at two different doses, $2 \mathrm{mg}$ and $100 \mathrm{mg}$, at different intervals (Table 1). The dose of the administered antigen had a significant impact on the type of immune response. Low doses of the antigen could induce tolerance through the active suppression mechanism, while the high dose - by deletion or anergy mechanism [17, 18].

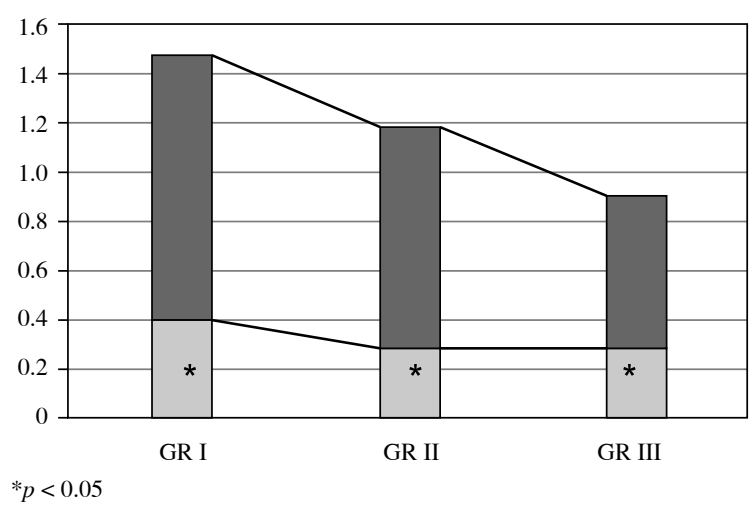

Fig. 3. OD levels of fecal extracts, for 14 and 49 days samples, from mice group I ( 2 mg OVA), II (100 $\mu \mathrm{g}$ OVA; 0,7 and 14 day) and III (100 $\mu$ g OVA; $0,1,2$ and 10 day)

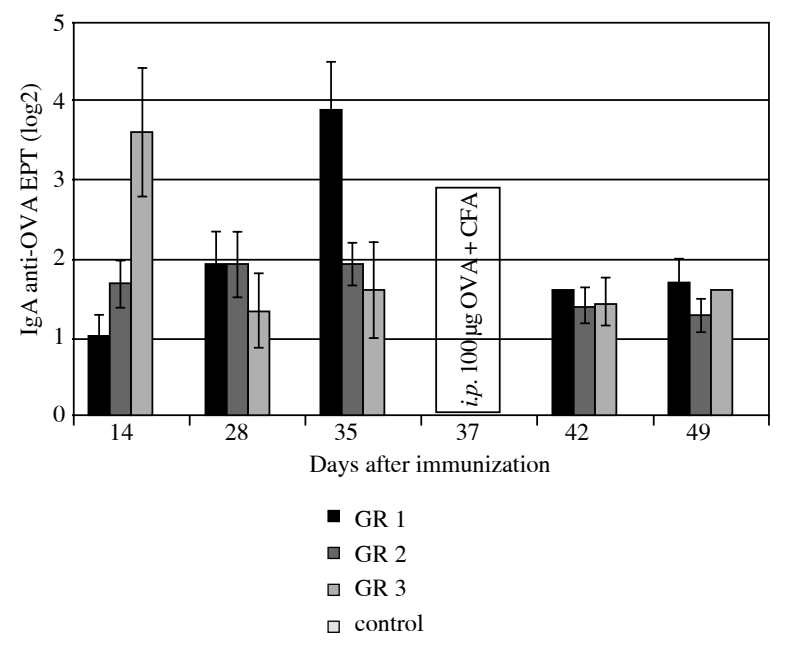

Fig. 2. The level of OVA-specific IgA serum depending on the dose of OVA. Values are expressed as means \pm SD

The level of specific IgG and IgA antibodies was examined in serum and fecal samples. Figure 1 shows the EPT of OVA-specific IgG antibodies in the studied groups during the experiment.

During the first 35 days of the experiment, the highest level of specific $\mathrm{IgG}$ was detected in the group immunized with a dose of $2 \mathrm{mg}$ of OVA, i.e. $2^{13}$ and $2^{11}$ after 14 and 35 days of the experiment, respectively. The dose of 100 $\mu \mathrm{g}$ of OVA (Groups II and III) regardless of the frequency of immunization (days $0,7,14$ or $0,1,2$ and 10), triggered a response of about three-folds lower. Statistical analysis showed significant differences $(p<0.05)$ of IgG titer between the Group I and remaining Groups II and III. No effect of immunization frequency was reported with respect to the induction of anti-OVA IgG. On day 37 after immunization mice were administered intraperitoneally a single dose of emulsion containing $100 \mu \mathrm{g}$ of OVA in CFA (complete Freund's adjuvant). One week later, all groups showed an increase in titer of anti-OVA IgG to a level of $2^{12-13}$. There were no statistically significant variations between groups. The intraperitoneal injection of OVA led to an equalization of specific IgG levels in all experimental groups. Furthermore, within the first 35 days, a significant effect of the dose of the antigen on the level of specific IgG induction was observed. This trend was also noted by other authors after mice immunization with a modified OVA in the presence of adjuvant [15, 19].

The titer of anti-OVA IgAs in blood serum was maintained at a low level throughout the duration of the experiment (Fig. 2). In the third group (dose of $100 \mathrm{mg}$, injections on days $0,1,2$ and 10), the highest IgA titer was observed already on day 14 after immunization. After following 14 days, all experimental groups presented a simi- 
lar level of specific IgA titer. Statistical analysis showed no significant differences in EPTs of specific IgAs in serum, even after additional intraperitoneal induction with $100 \mu \mathrm{g}$ of OVA in the presence of CFA.

Secretory sIgA levels in mouse fecal extracts are presented for particular groups as OD measured at $\chi=415 \mathrm{~nm}$ in undiluted samples. Figure 3 illustrates calculated means in groups studied after 14 and 49 days.

Peyer's patches are the main site of IgA synthesis. The experiment showed statistically significant differences between the tested groups of mice, indicating the proper antigen dose for induction of sIgA.

During the first 35 days of the experiment, both the amount and the method of antigen administration induced diverse immune responses of gut mucosa. The intraperitoneal dose of ovalbumin on day 37 caused an increase in the secretory levels of specific IgAs for all groups. This was confirmed by the results of ELISPOT assay on a cellular level, showing the presence of cells producing specific IgGs and IgAs in the population of lymphocytes of the spleen and Peyer's patches (unpublished data).

\section{Conclusions}

The proposed scheme of experiments made it possible to assess mucosal immune response, and to estimate the differences between the groups of experimental mice. The antigen dose significantly influenced the induction of specific IgGs. A high dose (2 mg) of OVA, administered orally, efficiently induced the production of specific antibodies of class $\mathrm{G}$ while production of class A specific antibodies, detected by ELISA test, was induced by both $2 \mathrm{mg}$ and $100 \mu \mathrm{g}$ doses of OVA.

The experimental model presented in the current study that makes use of Balb/C $\left(\mathrm{H}-2^{\mathrm{d}}\right)$ mice can be utilized in the analysis of the mucosal immune response to dietary allergens.

This study was funded by NCN grant 2011/01/B/ NZ9/02727.

\section{References}

1. Wershil BK, Furuta GT (2008): Gastrointestinal mucosal immunity. J Allergy Clin Immunol 121: 380-383.

2. Moreno FJ (2007): Gastrointestinal digestion of food allergens: Effect on their allergenicity. Biomed Pharmacother 61: $50-60$.

3. Alcocer M (2007): Food Allergens. Abstracts/Comparative Biochemistry and Pysiology. Part A 146: 245.

4. Mills ENC, Madsen C, Sherry PR, Wichers HJ (2007): Food allergens of plant origin-their molecular and evolutionary relationships. Trends Food Sci Tech 14: 145-156.

5. Jakóbisiak M, Gołąb J, Lasek W (2004): Immunologia. Wyd. PWN, Warszawa.
6. Pastuszka A, Ziółko E, Kuczmik W, et al. (2007): Śluzówkowy układ odpornościowy w układzie moczowo-płciowym. Urol Pol 60: 3.

7. Simecka JW (1998): Mucosal immunity of the gastrointestinal tract and oral tolerance. Adv Drug Deliv Rev 34: 235-259.

8. Macpherson AJ, Smith K (2006): Mesenteric lymph nodes at the center of immune anatomy. J Exp Med 203: 497-500.

9. Neutra MR, Frey A, Kraehenbuhl JP (1996): Epithelial M cells: gateways for mucosal infection and immunization. Cell 86: 345-348.

10. Allez M, Brimnes J, Dotan I, Mayer L (2002): Expansion of CD81 T cells with regulatory function after interaction with intestinal epithelial cells. Gastroenterology 123: 1516-1526.

11. Dahan S, Roth-Walter F, Arnaboldi A, et al. (2007): Epithelia: lymphocyte interactions in the gut. Immunol Rev 215: 243-253.

12. Bowman EP, Kuklin NA, Youngman KR, et al. (2002): The intestinal chemokine thymus-expressed chemokine (CCL25) attracts IgA antibody secreting cells. J Exp Med 195: 269-275.

13. Kaminogawa S, Hachimura S, Nakajima-Adachi H, Totsuka M (1999): Food allergens and mucosal immune system with special reference to recognition of food allergens by gut-associated lymphoid tissue. Allergol Int 48: 15-23.

14. Bartuzi Z (2007): Anafilaksja żołądkowo-jelitowa. Przegl Gastroenterol 2: 240-244.

15. Mierzejewska D, Mitrowska P, Rudnicka B, et al. (2008): Food Chemistry 111: 127-131.

16. Mierzejewska D (2000): Wpływ procesów termicznych i proteolizy na właściwości immunoreaktywne białek serwatkowych mleka krowiego: $\alpha$-laktoalbuminy i $\beta$-laktoglobuliny. Praca doktorska. IRZiBŻ PAN, Olsztyn.

17. Friedman A, Weiner HL (1994): Induction of anergy or active suppression following oral tolerance is determined by antigen dosage. Proc Natl Acad Sci U S A 91: 6688-6692.

18. Yoshida T, Hachimura S, Kaminogawa S (1997): The oral administration of low-dose antigen induces activation followed by tolerization, while high-dose antigen induces tolerance without activation. Clin Immunol Immunopathol 82: 207-215.

19. Rynda A, Maddaloni M, Mierzejewska D, et al. (2008): Lowdose tolerance is mediated by the microfold cell ligand, reovirus protein sigma1. J Immunol 180: 5187-5200. 